\title{
First report on the occurrence of plasticolous lichens from Uttarakhand, India
}

\author{
Vineeta J agtap, M anish Tripathi ${ }^{1}$ and Yogesh J oshi ${ }^{1 *}$
}

G. B. Pant Institute of Himalayan Environment and Development, Kosi Katarmal, Almora-263643 (Uttarakhand), INDIA ${ }^{1}$ Lichenology Division, Department of Botany, S.S.J. Campus, Kumaun University, Almora-263601 (Uttarakhand), INDIA

${ }^{*}$ Corresponding author. E-mail: dryogeshcalo@gmail.com

Received:A pril 10, 2013; Revised received:J une 15, 2013; Accepted: August 10, 2013

Abstract: The paper documents the distribution of three species [Hyperphyscia adglutinata (Flörke) H.Mayrhofer and Poelt, Paromotrema austrosinense (Zahlbr.) Hale and Punctelia subrudecta (Zahlbr.) Hale] of lichens from 14 years old nylon nets collected from Govind Ballabh Pant Institute of Himalayan Environment and Development (G.B.P.I.H.E.D.) located in temperate region of Central Himalaya. These three species were previously reported as corticolous and saxicolous, but for the first time are reported as plasticolous.

Keywords: Himalaya, Lichens, Plasticolous, Uttarakhand

\section{INTRODUCTION}

Lichens are self-supporting symbiotic associations formed by a fungus and one or several algal or cyanobacterial components as primary partners. Lichens have diversified extensively during the past 600 million years (Yuan et al., 2005), and occur over $>10 \%$ of the terrestrial surface. They are cosmopolitan in distribution and extend from maritime to arctic-boreal regions. They have the ability to grow on a wide variety of substrates such as rock, soil, leaves, bark, twigs and mosses, based on which they are classified as saxicolous, terricolous, foliicolous, corticolous, ramicolous and muscicolous etc. Certain species of lichens have become so adapted to these habitats that they never or rarely wander; others, on contrary, are true vagabonds in the lichen kingdom and settle on any substance that offers a foothold: on ropes, plastics, fences, glass, leather, bones, iron, pottery, aluminium roof etc. (Green and Snelgar, 1977, Brightman and Seaward, 1978, Sipman, 1994, Schroeter and Sancho, 1996, Schöller, 1997, Lücking, 1998, Gray, 1999, Mayrhofer et al., 2001; Lücking and Lücking, 2002; Upreti and Dixit, 2002; Christensen, 2004 and Lisická, 2008). Generally the term plasticolous is used for lichens colonizing plastics. The present work was initiated keeping an objective in mind to visualize lichen species colonizing man made substrata, which in near future will let us know about those species that can survive the destruction of their natural habitats by alternatively colonizing anthropogenic habitats.

\section{MATERIALS AND METHODS}

The present study is based on lichen specimens collected from 14 years old nylon nets (net house) in Govind Ballabh ISSN : 0974-9411 (Print), 2231-5209 (Online) All Rights Reserved ๑ Applied and Natural Science Foundation www.ansfoundation.org
Pant Institute of Himalayan Environment and Development (G.B.P.I.H.E.D.) and deposited at herbarium of Kumaun University, Uttarakhand, India. The nylon net house constructed in 1997, nine years after the establishment of the institute is used to protect cuttings and seedlings of medicinal plants during their juvenile stage. Morphological characters of thallus, reproductive structures, colour, size and shapes were examined under stereo zoom dissecting microscope. Hand-cut sections were made for studying the anatomy of thalli and fruiting bodies, and were examined under compound microscope. Spot test reactions were carried out on hand sections of thalli and apothecia under compound microscope. Thin layer chromatography (TLC) was performed as described by Orange et al. (2001).

\section{RESULTS}

The study documents the occurrence of three species of lichens [H yperphyscia adglutinata (Flörke) H.Mayrhofer and Poelt, Paromotrema austrosinense (Zahlbr.) Hale and Punctelia subrudecta (Zahlbr.) Hale] growing over nylon nets (Fig. 1). Hyperphyscia adglutinata belonging to the family Physciaceae, while Paromotrema austrosinense and Punctelia subrudecta of the family Parmeliaceae were previously reported growing over bark and rock in India (Divakar and Upreti, 2005, Awasthi, 2007 and Singh and Sinha, 2010).

This is for the first time that authors are reporting these species growing over nylon net expanding their substrate preference. Besides this, these species were not previously reported as plasticolous from any part of the Indian subcontinent. These species were growing on the outer side of the vertical surface of the net house, facing south-east direction. The most abundant amongst them 


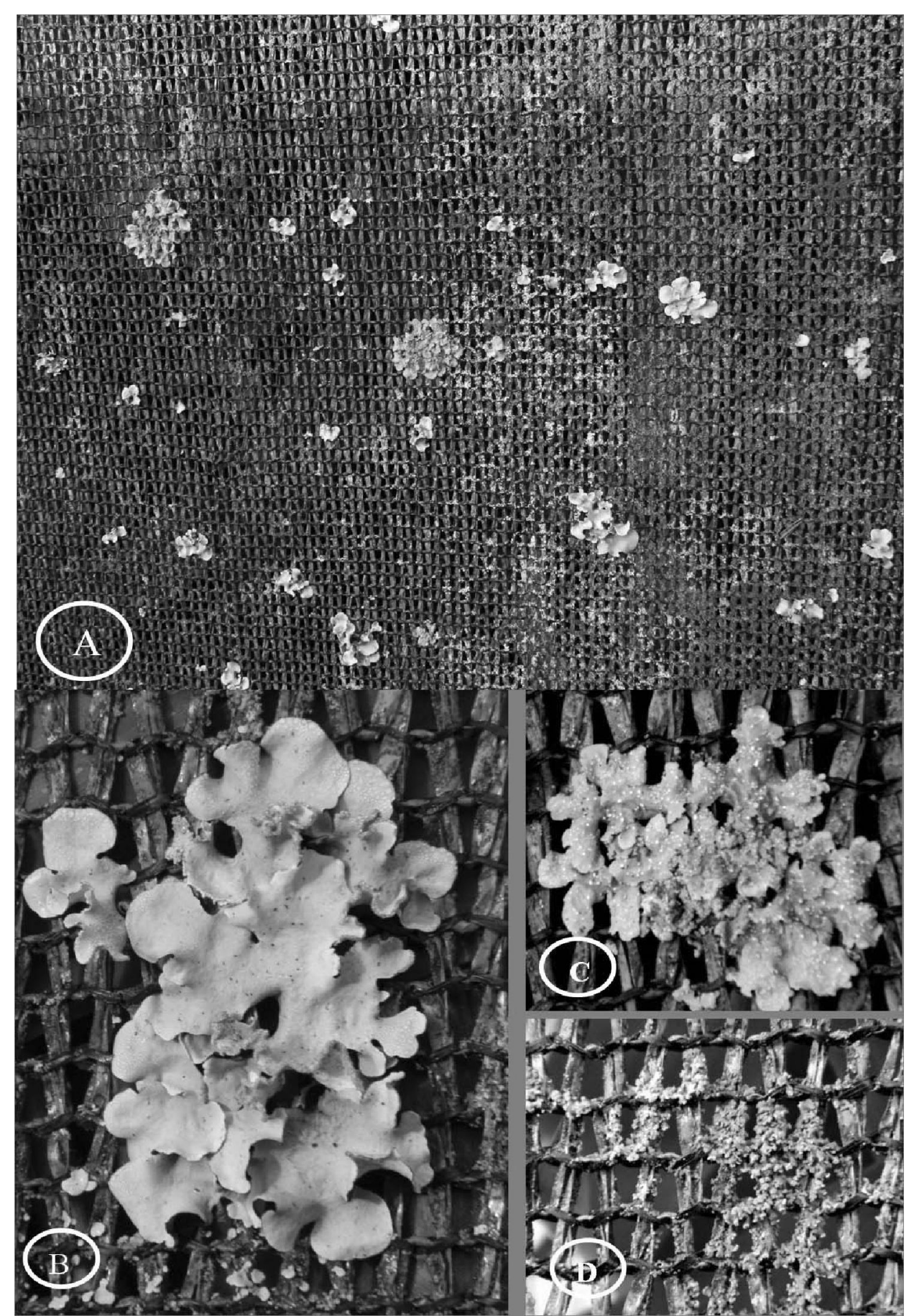

Fig. 1. Lichens growing on nylon net at G.B.P.I.H.E.D. (A) Species of lichens colonizing nylon net (B) M agnified view of Parmotrema austrosinense (C) Magnified view of Punctelia subrudecta (D) M agnified view of $\mathrm{H}$ yperphyscia adglutinata.

was $\mathrm{H}$. adglutinata, colonizing most part of the net.

\section{DISCUSSION}

The colonization of these species on nylon nets could be due to the smoothness of the surface, damp and moist microclimatic conditions, and the moisture retaining capacity of the nylon threads (Poelt and Vzda, 1990, Villwock, 1991, Lücking, 1998 and Upreti and Dixit, 2002) besides their luxuriant occurrence in and around poly house. Lücking (1998) mentioned that growth of lichens on artificial substrata showed that they may be able to survive the destruction of their natural habitats by alternatively colonizing anthropogenic habitats; similar things are happening in G.B.P.I.H.E.D. where lichens are growing on nylon nets. Besides this, other lichen species growing in the vicinity of poly house may in near future colonize these nylon nets.

\section{ACK NOW LEDGEMENTS}

One of the authors (Vineeta Jagtap) would like to thank 
D.S.T. for providing financial assistance and to Director, G.B.P.I.H.E.D. for providing laboratory facilities to work, while remaining authors would like to thank Head, Department of Botany, S.S.J. Campus, Almora for providing laboratory facilities and to Dr. D. K. Upreti in helping out lichen identification.

\section{REFERENCES}

Awasthi, D.D. (2007). A Compendium of the Macrolichens from India, Nepal and Sri Lanka. Bishen Singh Mahendra Pal Singh Publication, Dehra Dun, India.

Brightman, F.H. and Seaward, M.R.D. (1978). Lichens on manmade substrates. In: M.R.D. Seaward (Ed.), Lichen Ecology (pp. 253-293), London: Academic Press.

Christensen, S.N. (2004). Epilithic lichen vegetation of corrugated asbestos cement roof tiles in the Copenhagen area. Graphis Scripta, 15:7-13.

Divakar, P.K. and Upreti, D.K. (2005). Parmelioid lichens in India. A revisionary study. Bishen Singh Mahendra Pal Singh Publication, Dehra Dun, India.

Gray, J. (1999). Another good reason for buying a Lada car. British Lichen Society Bulletin, 85: 12-14.

Green, T.G.A. and Snelgar, W.P. (1977). Parmelia scabrosa growing on glass in New Zealand. Lichenologist, 9:170-172.

Lisická, E. (2008). Lichens on an acrylic-coated aluminium roof. Graphis Scripta, 20: 9-12.

Lücking, R. (1998). 'Plasticolous' lichens in a tropical rain forest at La Selva Biological station Costa Rica. Lichenologist, 30: 287-301.

Lücking, R. and Lücking, A.B. (2002). Distance dynamics and diversity in tropical rainforests: An experimental approach using foliicolous lichens on artificial leaves. I. Growth performance and succession. Ecotropica, 8: 1-13.

Mayrhofer, H., Lisická, E. and Lackovièová, A. (2001). New and interesting records of lichenized fungi from Slovakia. Biologia, Bratislava, 56: 355-361.

Orange A., James, P.W. and White, F.J. (2001). Microchemical methods for the identification of lichens. $101 \mathrm{pp}$. British Lichen Society, London.

Poelt, J. and Vzda, A. (1990). Ûber kurzlebige Flechten. Biblioth. Lichenol., 38: 377-394.

Schöller, H. (1997). Ökologie und Verbreitung. In: H. Schöller (Ed.), Flechten. Geschichte, Biologie, Systematik, Ökologie, Naturschutz und kulturelle Bedeutung. Begleitheft zur Ausstellung "Flechten-Kunstwerke der Natur", Kleine Senckenberg Reihe (pp. 83-109).

Schroeter, B. and Sancho, L.G. (1996). Lichens growing on glass in Antarctica. Lichenologist, 28: 385-390.

Singh, K.P. and Sinha, G.P. (2010). Indian Lichens: An Annotated Checklist, Botanical Survey of India, Kolkata.

Sipman, H.J.M. (1994). Foliicolous lichens on plastic tape. Lichenologist, 26: 311-312.

Upreti, D.K and Dixit, A. (2002). Lichens on plastic net. British Lichen Society Bulletin, 90: 60-67.

Villwock, G. (1991). Beitrege zur physischen Geographie and landschaftsgliederung des sudlichen Jemen (ehemals VDRJ). J emen-Studien, 10:1-207.

Yuan, X., Xiao, S. and Taylor, T.N. (2005). Lichen like symbiosis 600 million years ago. Science, 308: 1017 1020. 